Н. І. Рублевська, О. А. Шевченко, Г. С. Канюка, Ю. С. Крамарьова, С. А. Щудро, В. В. Зайцев, О. О. Кулагін, М. В. Дзяк ДЗ “Дніпропетровська медична академія МОЗ Украӥни”, м. Дніпро

\title{
АНАЛІЗ СТАВЛЕННЯ СТУДЕНТІВ ВИЩОГО МЕДИЧНОГО НАВЧАЛЬНОГО ЗАКЛАДУ ДО САМОСТІЙНОЇ РОБОТИ ЯК ВИДУ НАВЧАЛЬНОЇ ДІЯЛЬНОСТІ
}

\author{
N. I. Rublevska, O. A. Shevchenko, H. S. Kaniuka, Yu. S. Kramarova, \\ S. A. Shchudro, V. V. Zaitsev, O. O. Kulahin, M. V. Dziak
}

State Establishment "Dnipropetrovsk Medical Academy of Health Ministry of Ukraine”, Dnipro

\section{ANALYSIS OF THE HIGHER MEDICAL EDUCATIONAL INSTITUTION STUDENT'S ATTITUDE TO INDEPENDENT WORK AS AN EDUCATIONAL ACTIVITY TYPE}

\begin{abstract}
Мета роботи - вивчення організації і ставлення до самостійної роботи студентів медичного вищого навчального закладу. Основна частина. У статті наведено результати опитування серед студентів 3 та 6 курсів Дз “Дніпропетровська медична академія МОЗ України”, громадян України та іноземців, про їх ставлення до самостійної роботи при вивченні теоретичних та практичних дисциплін.

Висновки. Результати опитування серед студентів 3 та 6 курсів вищого медичного навчального закладу свідчать про необхідність пошуку ефективних засобів для підвищення їх відповідальності за кінцевий результат своєї освіти та зміни переважної пасивної ідеології навчання і відходу від споживчої парадигми при отриманні професійних знань. Показано, що більшість вітчизняних студентів (66,5 \%) негативно ставляться до самостійного пошуку і здобуття нових професійних знань, що обумовлює необхідність впровадження ефективних засобів для підвищення їх відповідальності за кінцевий результат своєї освіти та зміни переважної пасивної ідеології навчання.
\end{abstract}

Ключові слова: самостійна робота; опитування; впровадження ефективних засобів.

The aim of the study - to investigate organization and higher medical educational institutions student's attitude to independent work.

The main body. The results of a survey among students of $3^{\text {rd }}$ and $6^{\text {th }}$ years of State Establishment "Dnipropetrovsk Medical Academy of Health Ministry of Ukraine”, citizens of Ukraine and foreigners, about their attitude to independent work during theoretical and practical courses study are represented in the article.

Conclusion. The results of the survey among students of $3^{\text {rd }}$ and $6^{\text {th }}$ years of higher medical educational institutions show the necessity of finding effective methods to enhance their responsibility for the result of education and the vast changes the passive ideology of education. It was shown that the majority of students (66,5\%) have negative attitude towards an independent search and acquisition of new professional knowledge, which necessitates the implementation of effective tools to enhance their responsibility for the outcome of their education and the vast changes of passive ideology of learning.

Key words: independent work; survey; effective tools implementation.

Вступ. У даний час при підготовці майбутніх лікарів актуальною стає орієнтація навчального закладу на особу, що прагне саморозвитку, здатну самостійно поповнювати і оновлювати знання, вести самостійний пошук додаткового навчального матеріалу, творчо ставитись до виконання навчальних завдань. Вирішення цих завдань неможливе без підвищення ролі самостійної роботи студентів над навчальним матеріалом і посилення відповідаль-

( ) Н. І. Рублевська, О. А. Шевченко, Г. С. Канюка та ін. ності викладачів за розвиток у студентів навиків самостійної роботи, за стимулювання у них професійного зростання, творчої активності й ініціативи [1]. Впровадження в практику навчальних програм з підвищеною часткою самостійної роботи активно сприяє модернізації навчального процесу. Згідно 3 новими освітніми стандартами, питома вага самостійної роботи студентів має складати до 60 \% від загального навчального часу. Значення самостійної діяльності студентів важко переоцінити, оскільки 
з її допомогою вдається вирішити протиріччя між трансляцією знань і їх засвоєнням у взаємозв’ язку теорії і практики [2]. Лише через активну самостійну роботу, а не через сприйняття знань у готовому вигляді студент та лікар-інтерн можуть якісно опанувати спеціальні навички [3].

Самостійна робота - це вид навчальної діяльності, що виконується студентом без безпосереднього контакту з викладачем або керований викладачем опосередковано через спеціальні навчальні матеріали. У підготовці майбутніх фахівців самостійна робота виконує низку важливих виховних і освітніх функцій:

- розвиваючу - що сприяє підвищенню культури розумової праці, тренуванню когнітивних здібностей студентів;

- інформаційно-навчальну - що сприяє підвищенню професійної ерудиції і умінню працювати з великим об’ємом інформації;

- орієнтуючу і стимулюючу - що додає процесу навчання професійне прискорення;

- виховну - що формує і розвиває професійні якості фахівця;

- дослідницьку - що сприяє розвитку творчого мислення майбутнього лікаря.

Незважаючи на те, що самостійна робота студентів є чи не найбільш ефективною формою навчальної роботи, організація іï̈ - це один з найбільш складних моментів навчального процесу у навчальному закладі. У порівнянні з аудиторними формами роботи (лекціями, практичними заняттями, семінарами) самостійна робота, з одного боку, виявляється такою, що найменш піддається управлінню ззовні, з іншого - може бути ефективною лише при щирій зацікавленості студента в самостійному вивченні матеріалу для досягнення загальної мети свого навчання.

Мета роботи - вивчення організації і ставлення до самостійної роботи студентів медичного ВНЗ. Дослідження, у якому взяли участь студенти 6-го курсу (61 особа) і студенти-іноземці 3-го курсу (45 осіб), проводили на кафедрі гігієни і екології Д3 “Дніпропетровська медична академія МО3 України” у лютому - березні 2017 року.

Студентам була запропонована анонімна анкета, яка стосувалася таких питань, як: розуміння значущості самостійної роботи у ВНЗ; необхідних витрат часу на самостійну підготовку до теоретичних і клінічних дисциплін; контролю засвоєного навчального матеріалу за допомогою самостійної роботи тощо. Цікаво було зіставити відповіді сту- дентів випускного курсу з відповідями іноземних студентів, які вчаться на 3-му курсі.

Основна частина. Результати дослідження показали, що у студентів існує різне ставлення до самостійної роботи як форми навчання. Серед вітчизняних студентів позитивно ставляться до самостійної роботи тільки 19,5 \% опитаних, а негативну оцінку такому виду діяльності дають 66,5 \% респондентів. При порівнянні цих результатів з відповідями іноземних студентів встановлено, що позитивно оцінюють самостійну роботу 91 \% опитаних. Такий різнобій в отриманих даних свідчить не лише про різне розуміння вітчизняними й іноземними студентами значення і функцій самостійної роботи в підготовці майбутніх фахівців, але і про недостатньо зрілу соціальну позицію наших випускників. Це підтверджується відповідями студентів на питання про те, яка кількість часу від загального числа навчальних годин має приділятися самостійній роботі. Відповіді показали, що кожен 3-й опитаний (37 \%) шестикурсник вважає, що досить 20 \% навчального часу, і тільки 4,9 \% усіх респондентів упевнені, що самостійній роботі повинно приділятися 60 \% навчального часу студента. Відрізняються думки вітчизняних і зарубіжних студентів з питання кількості годин, відведених на вивчення теоретичних і клінічних дисциплін. Більшість опитаних іноземних студентів (71 \%) вважає, що на самостійну роботу як по теоретичних, так і по клінічних дисциплінах необхідно відводити однакову кількість часу. Більшість вітчизняних студентів (91,5 \%) не згодна з такою думкою, оскільки їм на самостійну підготовку по цих дисциплінах потрібна різна кількість годин. У ході дослідження встановлено, що самостійна підготовка до кожного аудиторного теоретичного заняття у більшості опитаних вітчизняних студентів (46,8 \%) і студентів-іноземців (62 \%) займає 1-2 год. При підготовці до аудиторних клінічних дисциплін така ж кількість годин потрібна 39,5 \% опитаних вітчизняних студентів і кожному третьому іноземному (31 \%), а більше 2-3-х годин самостійної роботи йде у кожного другого вітчизняного респондента (57,5 \%) і у 28 \% студентів-іноземців. Якщо аналізувати підготовку до кожного позааудиторного заняття, то теоретичним дисциплінам більшість вітчизняних студентів (43,3 \%) приділяють менше однієї години, а іноземні студенти (31 \%) від одної до двох годин. По клінічних дисциплінах витрати часу на самостійну роботу наступні: менше однієї години йде у 24,6 \% вітчизняних студентів 
i у 28 \% іноземних респондентів; 1-2 години у 36,2 \% вітчизняних і у 31 \% іноземних студентів; від 2-х до 3-х годин - у 26,5 \% вітчизняних і у $13 \%$ іноземних опитаних; більше 3-х годин у 12,7 \% наших студентів і у 6 \% іноземних.

Більшість студентів, що брали участь в опитуванні, як вітчизняних (89,3 \%), так і іноземних (78 \%) вважають, що кількість часу, який йде у них на самостійну підготовку до заняття, залежить від їх зацікавленості у вивченні конкретної дисципліни і складності тієї або іншої теми (96,7 \% вітчизняних студентів і 71 \% іноземців). Серед видів самостійних робіт більшість шестикурсників використовує конспектування (66 \%) і підготовку презентацій (59 \%), а іноземні студенти вирішують ситуаційні завдання (44 \%). При самостійному оволодінні позааудиторними темами 90 \% наших студентів і 89 \% іноземців потребують консультації викладачів. Контроль самостійно засвоєного позааудиторного матеріалу, на думку студентів, повинен здійснюватися на практичних заняттях 3 кожного окремого модуля. Так вважають 43,5 \% наших випускників і 58 \% опитаних студентів-іноземців. Відповіді на контрольні питання тем для самостійної роботи більшості вітчизняних (78 \%) й іноземних студентів (49 \%) зручніше шукати в навчально-методичних посібниках, розроблених викладачами кафедри. При цьому кожен третій вітчизняний (35 \%) та іноземний студент (35 \%) користується інформацією з електронних ресурсів. Проте слід звернути увагу на те, що тільки 8,3 \% вітчизняних студентів і 28 \% іноземних респондентів звертаються за відповідями на контрольні питання до підручників. Це свідчить про те, що у багатьох студентів немає установки на копітку працю, спрямовану на якісний пошук необхідної інформації. Більшість майбутніх фахівців вважає за краще отримувати відповіді в готовому вигляді, без самостійного їх пошуку і осмислення.

Аналіз інформації, отриманої при анонімному анкетуванні студентів, свідчить у цілому про неготовність більшої частини респондентів до зміни ідеології навчання та відходу від споживчої парадигми при отриманні професійних знань. Ситуацію дуже влучно описують рядки із відомого вірша В. В. Маяковського “Кем быть?”: “... инженеру хорошо, а доктору - лучше, я б детей лечить пошел, пусть меня научат”. Останню фразу можна, на жаль, вважати квінтесенцією ставлення значної кількості сучасних студентів до навчання. "Нехай мене навчать” - слова не суб’єкта, а об’єкта на- вчання, людини, яка не вважає необхідним брати на себе відповідальність за кінцевий результат своєї освіти, обираючи при цьому не “вудку”, а вже готову “рибу”. Показовою в цьому сенсі $є$ помітна різниця у відповідях вітчизняних та іноземних студентів. Останні, навчаючись цілком на комерційній основі, більш прагматично підходять до процесу отримання знань та не нехтують шансом для використання всіх освітніх можливостей, що надає ВН3, у тому числі і при виконанні самостійних фрагментів роботи (більше 90 \% позитивних відповідей). Готуючись до непростого кваліфікаційного підтвердження якості своїх професійних знань та навичок на батьківщині, ці студенти також більш рівноцінно ставляться до теоретичних та практичних дисциплін. Цікаво, що майже тотожні відповіді отримані нами відносно мотиваційного заохочення до самостійного опанування навчального матеріалу: і українські, і іноземні студенти готові глибше вивчати теми, які їх зацікавили, або ж є важкими для засвоєння. I тут не можна не згадати одне 3 найважливіших завдань викладача - пробудити інтерес студента до своєї дисципліни, будучи при цьому не тільки добрим фахівцем у своїй галузі, але й лідером, партнером, людиною, від якої хочеться навчитись. Не випадково переважна більшість опитаних в обох групах визнає необхідність консультацій викладача при опануванні тем для самостійного вивчення. Звертає на себе увагу структура джерел, яким надають перевагу респонденти при засвоєнні позааудиторних тем. I вітчизняні, i іноземні студенти активно і рівною мірою користуються електронними джерелами інформації та кафедральними посібниками, при цьому практично ігноруючи рекомендовані підручники. Це підтверджує загальносвітову тенденцію швидкого старіння інформації, коли об’ємні класичні керівництва на паперових носіях просто не встигають за розвитком знань. 3 іншого боку, студенти надають перевагу менш змістовним і розлогим, але легшим для засвоєння та користування методичним посібникам та матеріалам з IT-мереж. При цьому виникає загроза певної профанації рівня професійних знань, особливо при користуванні неспеціальними електронними ресурсами, та покладає особливу відповідальність на кафедральних співробітників викладачів і розробників дидактичних матеріалів.

Висновки. 1. Самостійна робота студентів залишається найбільш складною та актуальною формою навчальної роботи у навчальному закладі, питома вага якої, згідно з новими освітніми 
стандартами, може складати до 60 \% від загального навчального часу. Вона найменш піддається управлінню ззовні та може бути ефективною лише при щирій зацікавленості студента в самостійному вивченні матеріалу для досягнення загальної мети свого навчання.

2. Проведене опитування серед студентів 3 та 6 курсів вищого медичного навчального закладу

\section{Список літератури}

1. http://pidruchniki.com/70160/pedagogika/suchasni tehnologiyi_navchannya_vischomu_navchalnomu_zakladi.

2. Бистрова Ю. В. Інноваційні методи навчання у вищій школі України [Електронний ресурс] / Ю. В. Бистрова // Право та інноваційне суспільство : електрон. наук. вид. - 2015. - № 1 (4). - Режим доступу : http://apir.org. ua/ wp-content/uploads/2015/04/Bystrova.pdf.

\section{References}

1. Suchasni tekhnolohii navchannia u vyshchomu navchalnomu zakladi [Modern education technology at higher educational institution]. Retrieved from http://pidruchniki. com/70160/pedagogika/suchasni_tehnologiyi_navchannya_ vischomu_navchalnomu_zakladi [in Ukrainian].

2. Bystrova, Yu. (2015). Pravo ta innovatsiine suspilstvo [Law and innovative society]. Retrieved from http://apir. org.ua/wp-content/uploads/2015/04/Bystrova.pdf [in Ukrainian].

Електронна адреса для листування: julia-grata@rambler.ru свідчить про необхідність пошуку ефективних засобів для підвищення їх відповідальності за кінцевий результат своєї освіти та зміни переважної пасивної ідеології навчання (“нехай мене навчать”) і відходу від споживчої парадигми при отриманні професійних знань.

3. Сучасні методи тестування у підготовці лікарівінтернів / О. Я. Бабак, Г. Ю. Панченко, М. І. Кліменко [та ін.] // Інноваційні технології в системі професійної підготовки студентів в XНMУ : матеріали XLVIII навч.метод. конф. (Харків, 10 грудня 2014 року). - Х., 2014. С. 23-26.

3. Babak, O.Ya., Panchenko, H.Yu., Klimenko, M.I., Masliaieva, L.V., Frolova-Romaniuk, Ye.Yu., Zaichenko, O.Ye, \& Nesterova, I.A. (2014). Suchasni metody testuvannia u pidhotovtsi likariv-interniv [Modern testing methods in the training of internship doctors]. Proceedings from ITSPTKhNMUS'14: Navch.-metod. conf. “Innovatsiini tekhnolohii v systemi profesiinoi pidhotovky studentiv $v$ KhNMU" - Learning and teaching conference "Innovative technologies in the system of professional training of KhNMU students”. (pp. 23-25). Kharkiv: KhNMU [in Ukrainian]. 